\title{
Optimalisasi Pemanfaatan Akses Digital Repository dalam Menunjang Tri Dharma Perguruan Tinggi (Studi Kasus di Perpustakaan Universitas Muhammadiyah Yogyakarta)
}

\author{
Aidilla Qurotianti ${ }^{*}$; Fifin Rokhimatun ${ }^{2}$ \\ ${ }^{1}$ Perpustakaan Universitas Muhammadiyah Yogyakarta \\ ${ }^{2}$ Perpustakaan Universitas Muhammadiyah Yogyakarta \\ *Korespondensi: aidila_qurotianti@yahoo.co.id
}

\begin{abstract}
The progress of the digital era has made society, especially students, rely on searching for sources of references via the internet that are considered practical and efficient. The high level of student mobility makes it easy for them to search for information using the internet. The library must keep up with the times, so the UMY Library is present to provide digital repository facilities that can be accessed easily, precisely and efficiently. The purpose of this study was to determine the optimization of the use of digital repository access to support the Tri Dharma Perguruan Tinggi at Universitas Muhammadiyah Yogyakarta Library. The results of this study indicate that there are several ways to optimizing the use of digital repository access in supporting the Tri Dharma Perguruan Tinggi at Universitas Muhammadiyah Yogyakarta Library, among others: 1) Leaflets and X-Banners, 2) Socialization, 3) Social Media, and 4) Information Literacy. Efforts to optimize digital repository are very helpful for the achievement of the Tri Dharma Perguruan Tinggi at Universitas Muhammadiyah Yogyakarta.
\end{abstract}

Keywords: Digital Repository; Tri Dharma Perguruan Tinggi; Education; Human Resources 


\begin{abstract}
Abstrak
Kemajuan era digital membuat masyarakat khususnya mahasiswa mengandalkan pencarian sumber referensi melalui internet yang dinilai praktis dan efisien. Tingkat mobilitas di kalangan mahasiswa yang cukup tinggi membuat mereka mudah dalam mencari informasi menggunkan internet. Dunia Perpustakaan harus mengikuti arus zaman sehingga Perpustakaan UMY hadir dalam memberikan fasilitas digital repository yang dapat diakses dengan mudah, tepat dan efisien. Tujuan dari penelitian ini adalah untuk mengetahui optimalisasi pemanfaatan akses digital repository dalam menunjang Tri Dharma Perguruan Tinggi di Perpustakaan Universitas Muhammadiyah Yogyakarta (UMY). Hasil penelitian ini menunjukkan bahwa optimalisasi pemanfaatan akses digital repository dalam menunjang Tri Dharma Perguruan tinggi di Perpustakaan Universitas Muhammadiyah Yogyakarta dilakukan berbagai cara, antara lain melalui: 1) Leaflet dan X-Banner, 2) Sosialisasi, 3) Media Sosial, dan 4) Literasi informasi. Usaha dalam mengoptimalkan digital repository akan sangat membantu dalam pencapaian Tri Dharma Perguruan Tinggi di Universitas Muhammadiyah Yogyakarta.
\end{abstract}

Kata kunci: Digital Repository; Tri Dharma Perguruan Tinggi; Pendidikan; Sumber Daya Manusia

\title{
Pendahuluan
}

Tidak dapat dipungkiri bahwa masyarakat kita saat ini bisa dikatakan sudah ketergantungan dengan kemudahan internet yang praktis dan efisien karena faktor mobilitas yang cukup tinggi bagi sebagian orang khususnya mahasiswa. Tingkat kebutuhan referensi informasi dan ilmu pengetahuan mahasiswa semakin tinggi dan beragam, sehingga mereka membutuhkan beberapa rujukan referensi dalam mendukung penyelesaian tugas mata kuliah, karya tulis, maupun laporan studi lapangan secara mudah,tepat dan efisien.

Salah satu fenomena era digital saat ini berdampak pada cara mahasiswa dalam memperoleh sumber referensi informasi dan ilmu pengetahaun untuk menyelesaiakan tugas kuliah mereka. Hal tersebut membuat mereka selalu mengacu kepada internet dalam proses pencarian sumber bahan referensi tugas mereka karena alasan mudah dan cepat, namun belum tentu tepat dan efisien. Faktor tepat dan efisien tersebut membuat perpustakaan perguruan tinggi harus menyediakan bahan referensi informasi dan ilmu pengetahuan yang dapat diakses oleh mahasiswa dimana saja dan 
kapan saja sehingga dapat menerapkan Tri Dharma Perguruan Tinggi yang terdiri dari pendidikan, penelitian dan pengembangan, serta pengabdian kepada masyarakat.

Demi terselenggarakannya Tri Dharma Perguruan Tinggi di sebuah universitas, maka sebuah perpustakaan di perguruan tinggi dituntut untuk dapat memberikan kemudahan akses referensi informasi dan ilmu pengetahuan kepada para mahasiswa agar dapat memperkaya khazanah pengetahuan yang bermanfaatkan bagi kemajuan perguruan tinggi tersebut. Pada era digital saat ini perpustakaan perguruan tinggi dituntut untuk menyediakan sumber referensi informasi yang tidak hanya berupa bahan pustaka fisik, namun perpustakaan perguruan tinggi juga harus berkemajuan dan berinovasi dalam menyediakan sumber referensi informasi digital yang dapat diakses secara mudah, tepat dan efisien, sehingga mahasiswa dapat terarah dalam mencari sumber rujukan referensi informasi yang valid. Bahan pustaka informasi digital merupakan bahan pustaka atau bahan informasi yang telah diubah menjadi digital/soft file yang diupload oleh sebuah perpustakaan atau yang dikenal dengan nama perpustakaan digital.

Dalam sebuah perpustakaan digital terdapat istilah institutional repository yang erat kaitannya dengan pengembangan perpustakaan digital. Menurut Pendit (2008: 137) istilah institutional repository atau "simpanan kelembagaan" merujuk ke sebuah kegiatan menghimpun dan melestarikan koleksi digital yang merupakan hasil karya intelektual dari sebuah komunitas tertentu. Institutional repository atau yang sekarang lebih dikenal dengan nama digital repository seringkali dikaitkan dengan upaya menghimpun karya-karya intelektual dan materi ilmiah para civitas akademika disebuah perguruan tinggi dalam format digital yang dapat diakses secara online. Kemajuan dalam bidang sumber daya digital yang dimiliki sebuah perguruan tinggi tidak hanya memberikan keuntungan kepada mahasiswa semata, tapi juga akan memberikan keuntungan reputasi baik bagi perguruan tinggi tersebut. Ketika semakin banyak penulis mengutip karya akademisi perguruan tinggi tertentu, maka reputasi perguruan tinggi tersebut akan semakin diakui dalam bidang pengetahuan tertentu. 
Namun hambatan dalam pemanfaatan digital repository tersebut masih belum maksimal dikarenakan faktor kurangnya promosi atau sosialisasi kepada mahasiswa maupun dosen di perguruan tinggi. Hal tersebut akan membuat peran digital repository dalam menunjang kebutuhan pendidikan, penelitian, serta pengabdian kepada masyarkat atau yang dikenal dengan nama Tri Dharma Perguruan Tinggi menjadi kurang terlaksana dengan baik. Salah satu Perpustakaan perguruan tinggi yang memiliki strategi dalam mengoptimalkan akses digital repository dalam menunjang Tri Dharma Perguruan Tinggi adalah Perpustakaan Universitas Muhammadiyah Yogyakarta.

Berdasarkan uraian paparan masalah di atas, maka rumusan masalah dalam makalah ini adalah bagaimana optimalisasi akses digital repository dalam menunjang Tri Dharma Perguruan Tinggi di Perpustakaan Universitas Muhammadiyah Yogyakarta? Melalui makalah ini diharapkan mampu mendeskripsikan optimalisasi pemanfaatan akses digital repository dalam menunjang Tri Dharma Perguruan Tinggi di Perpustakaan Universitas Muhammadiyah Yogyakarta.

\section{Tinjauan Pustaka}

\section{a. Perpustakaan Digital}

Menurut The Digital Library Federation sebagai perwakilan dari komunitas yang terdiri dari para praktisi yang dikutip dari Pendit (2007: 29) mendefinisikan bahwa:

"Digital libraries are organizations that provide the resources, including the specialized staff, to select, structure, offer intellectual access to, interpret, distribute preserve the integrity of, and ensure the persistence over time of collections of digital works so that they are readily and economically available for use by a defined community or set of communities".

(Perpustakaan digital adalah berbagai organisasi yang menyediakan sumber daya, termasuk pegawai yang terlatih khusus, untuk memilih, mengatur, menawarkan akses, memahami, menyebarkan, menjaga integritas, dan memastikan keutuhan karya digital, sedemikian rupa sehingga koleksi 
tersedia dan terjangkau secara ekonomis oleh sebuah atau sekumpulan komunitas yang membutuhkannya).

Definisi di atas menjelaskan bahwa perpustakaan digital merupakan yang upaya teroganisir dalam memenuhi kebutuhan masyarakat penggunanya dengan memanfaatkan sumber daya manusia untuk memilih, mengatur, menawarkan akses, menyebarkan, serta menyusun dan mengolah bahan pustaka yang ada di perpustakaan dalam bentuk digital serta menawarkan akses intelektual kepada pemakai/pemustaka. Sedangkan menurut Sulistyo Basuki (2010: 2.45) menjelaskan bahwa perpustakan digital adalah kumpulan materi media campuran dalam bentuk digital yang diatur dan dikelola untuk kepentingan populasi pemakai tertentu, distruktur untuk memudahkan fasilitas akses atau memasuki isi perpustakaan dan dilengkapi dengan alat bantu navigasi ke jaringan informasi global.

Dari uraian diatas maka dapat disimpulkan bahwa perpustakaan digital adalah upaya terorganisir yang memanfaatkan sumber daya manusia dalam memilih, mengolah, dan mengatur kumpulan materi media campuran dalam bentuk digital yang dikelola untuk memenuhi kepentingan dan kebutuhan masyarakat penggunanya dengan memudahkan fasilitas akses ke jaringan informasi global.

Menurut Pendit (2009: 51) adanya inisiatif pengarsipan terbuka sebagai fenomena yang mencerminkan pengaruh teknologi informasi terhadap kebebasan akademik, sekaligus membuat tata aturan baru mengenai pemanfaatan teknologi di bidang pendidikan tinggi dimana karya-karya digital dapat diakses melalui perangkat lunak yang bersifat terbuka, misalnya E-print dan Dspace. Karya-karya digital ini dapat saling berhubungan melalui jaringan internet. Perpustakaan Universitas Muhammadiyah Yogyakarta memanfatakan perangkat lunak DSpace yang dapat diakses melalui repository. umy.ac.id. Dari segi inilah dapat terlihat peranan perpustakaan sebagai lembaga penghimpun atau dapat disebut pula institutional repository.

Sebelum menggunakan Dspace, Perpustakaan Universitas Muhammadiyah Yogyakarta menggunakan digital repository dengan 
alamat website thesis.umy.ac.id. Pada digital repository tersebut dibuat dan dikembangkan sendiri oleh pihak Perpustakaan Univesitas Muhammadiyah Yogyakarta. Setelah diadakan evaluasi, digital repository tersebut terdapat beberapa kekurangan yaitu tidak terindeks melalui google scholar dalam temu kembali informasi. Akibatnya data yang telah masuk sulit ditemukan kembali. Pada tahun 2016, Perpustakaan Universitas Muhammadiyah Yogyakarta melakukan transformasi menggunakan digital repository melalui perangkat lunak Dspace yang dapat diakses melalui repository.umy.ac.id.

Secara sederhana menurut Suwardi (2014) institutional repository sebagai tempat untuk menyimpan barang-barang berharga yang berhubungan dengan suatu lembaga. Institutional repository mempunyai dua tujuan/sasaran pokok menurut Vishala and Bhandi dalam Suwardi (2014) yaitu:

1. Menyediakan akses terbuka ke hasil penelitian institusional dengan pengarsipan sendiri hasil penelitian tersebut,

2. Menyimpan dan melestarikan aset digital institusional lainnya, meliputi literatur yang tidak diterbitkan atau yang mudah hilang (misal thesis atau laporan teknis).

\section{b. Perpustakaan dan Tri Dharma Perguruan Tinggi}

Menurut UU No. 12 Tahun 2012 tentang Pendidikan Tinggi Pasal 1 Ayat 9 Tri dharma Perguruan Tinggi yang selanjutnya disebut Tridharma adalah kewajiban Perguruan Tinggi untuk menyelenggarakan pendidikan, penelitian, dan pengabdian kepada masyarakat. Suatu perguruan tinggi berkewajiban memberikan pendidikan layak yang sesuai dengan kurikulum yang berlaku, mewujudkan suasana dan pengajaran belajar yang baik dan kondusif, dan mengembangkan potensi diri mahasiswa yang meliputi kekuatan spiritual keagamaan, akhlak dan etika sopan santun, kepribadian, kecerdasan, serta keterampilan.

Perguruan tinggi juga berkewajiban dalam memberikan bimbingan dan motivasi kepada mahasiswa dalam melakukan kegiatan penelitian dalam menguji suatu cabang ilmu pengetahuan dan teknologi, serta memberikan pendampingan dan pengarahan kepada mahasiswa dalam 
melakukan kegiatan pengabdian kepada masyarakat yang memanfaatkan ilmu pengetahuan dan teknologi untuk memajukan kesejahteraan masyarakat dan mencerdaskan kehidupan bangsa.

Kegiatan yang mencakup tri dharma perguruan tinggi tersebut tidak lepas dari peran serta perpustakaan dalam memberikan fasilitas dan dukungan secara teori. Menurut Suwarno (2016: 55) mengatakan bahwa perpustakaan sebagai lembaga yang memberikan layanan jasa informasi dan menjadi salah satu pusat informasi. Perpustakaan menghimpun, mengelola, menyimpan, melestarikan, menyajikan, serta memberdayakan informasi yang mencakup segala bidang pendidikan. Peran vital perpustakaan tersebut menimbulkan istilah perpustakaan sebagai “jantung perguruan tinggi” karena perpustakaan memiliki peranan penting di dunia pendidikan, penelitian, dan pengabdian kepada masyarakat.

\section{Metode}

Penelitian ini merupakan jenis penelitian deskriptif kualitatif dengan menggunakan metode studi kasus. Menurut Sulistyo Basuki (2006: 113) studi kasus adalah kajian secara mendalam tentang suatu peristiwa, lingkungan, dan situasi tertentu dalam mengungkapkan atau memahami sesuatu. Teknik pengumpulan data yang peneliti gunakan yakni metode wawancara dan observasi. Wawancara dilakukan kepada pustakawan bagian repository UMY. Sedangkan observasi dilakukan peneliti dengan terjun langsung melihat dan ikut serta dalam proses optimalisasi pemanfaatan digital repository kepada civitas akademika UMY.

\section{Hasil dan Pembahasan}

\section{a. Optimalisasi Akses Digital Repository}

Perpustakaan Universitas Muhammadiyah Yogyakarta (UMY) memiliki berbagai macam bahan referensi informasi dan ilmu pengetahuan yang disajikan dalam berbagai bentuk, baik itu fisik maupun non fisik (digital). Dalam menyediakan sumber referensi dalam bentuk digital, Perpustakaan 
Universitas Muhammadiyah Yogyakarta memiliki dua website yaitu $w w w$. thesis.umy.ac.id dan www.repository.umy.ac.id. Di dalam kedua web tersebut terdapat berbagai macam bahan referensi informasi yang meliputi: e-skripsi, e-book, hasil penelitian para dosen, dsb. Melaui website tersebut mahasiswa maupun dosen dapat mengakses dan memperoleh berbagai macam bahan referensi dan ilmu pengetahuan dalam bentuk soft file / digital yang dapat diakses dimana saja dan kapan saja secara cepat dan efisien sesuai dengan kebutuhan. Selain itu Perpustakaan Universitas Muhammadiyah Yogyakarta juga memiliki langganan e-jurnal di website www.library.umy.ac.id yang dapat diakses oleh mahasiswa Universitas Muhammadiyah Yogyakarta sesuai dengan kebutuhan mahasiswa Universitas Muhammadiyah Yogyakarta.

Dalam pengoptimalan pemanfaatan akses digital repository kepada mahasiswa maupun dosen, Perpustakaan Universitas Muhammadiyah Yogyakarta melakukan beberapa bentuk promosi tentang fasilitas maupun layanan digital repository yang disediakan oleh Perpustakaan Universitas Muhammadiyah Yogyakarta, antara lain:

a. Leaflet

Leaflet merupakan selebaran publikasi yang berisi tentang keterangan atau informasi tentang suatu instansi atau perusahaan. Dalam hal ini leaflet yang dibuat oleh Perpustakaan Universitas Muhammadiyah Yogyakarta berisi tentang informasi, berbagai layanan, serta fasilitas yang disediakan oleh Perpustakaan Universitas Muhammadiyah Yogyakarta termasuk akses referensi digital, sehingga mahasiswa dapat mengetahui link website yang menyediakan sumber referensi digital yang dimiliki Perpustakaan Universitas Muhammadiyah Yogyakarta. Leaflet tersebut diletakkan di meja informasi Perpustakaan Universitas Muhammadiyah Yogyakarta yang strategis dan banyak dilewati mahasiswa, sehingga mahasiswa dapat melihat leaflet tersebut dan dapat mengambilnya.

b. X-Banner

$\mathrm{X}$-Banner merupakan sebuah media yang digunakan untuk menampilkan informasi berbentuk banner dengan bentuk penyangga belakang 
berbentuk "X". Hampir sama seperti halnya peran leaflet, namun bentuk penyajian informasi pada X-Banner yang dibuat oleh Perpustakaan Universitas Muhammadiyah Yogyakarta hanya menampilkan garis besar dan hanya memuat satu topik, yaitu berisi tentang informasi akses e-jurnal yang dapat diakses melalui www.library.umy.ac.id dan diletakkan di sudut-sudut ruang yang strategis, baik itu di Perpustakaan Pusat Universitas Muhammadiyah Yogyakarta maupun Perpustakaan Fakultas di Universitas Muhammadiyah Yogyakarta.

c. Sosialisasi

Kegiatan sosialisasi yang dilakukan oleh para pegawai perpustakaan UMY dilaksanakan dalam acara MATAF (Masa Taaruf Siswa) atau di beberapa perguruan tinggi lebih dikenal dengan sebutan OSPEK (Orientasi Studi dan Pengenalan Kampus) kepada seluruh mahasiswa baru Universitas Muhammadiyah Yogyakarta. Langkah tersebut ditujukan agar seluruh mahasiswa baru Universitas Muhammadiyah Yogyakarta nantinya akan dapat memanfaatkan fasilitas dan layanan Perpustakaan Universitas Muhammadiyah Yogyakarta khususnya fasilitas digital repository. Melalui kegiatan tersebut diharapkan seluruh mahasiswa Universitas Muhammadiyah Yogyakarta dapat mengetahui dan mengenal bagaimana peran dan manfaat Perpustakaan UMY, baik dari segi koleksi bahan pustaka, fasilitas, layanan, serta sumber daya digital yang dimiliki oleh Perpustakaan Universitas Muhammadiyah Yogyakarta.

d. Media Sosial

Media sosial merupakan media online yang sudah tidak asing lagi di telinga masyarakat terutama kalangan mahasiswa. Fenomena ini dimanfaatkan oleh Perpustakaan Universitas Muhammadiyah Yogyakarta dalam mempromosikan dan mensosialisasikan Perpustakaan Universitas Muhammadiyah Yogyakarta kepada mahasiswa. Media sosial yang digunakan oleh Perpustakaan Universitas Muhammadiyah Yogyakarta dalam memperkenalkan digital repository antara lain facebook (Perpustakaan UMY) dan twitter (@PerpustakaanUMY) yang dikelola 
oleh pegawai perpustakaan Universitas Muhammadiyah Yogyakarta.

e. Literasi Informasi

Literasi informasi atau sering disingkat LI merupakan kegiatan kelas yang diadakan oleh Perpustakaan Universitas Muhammadiyah Yogyakarta yang ditujukan bagi para civitas akademika khususnya mahasiswa Universitas Muhammadiyah Yogyakarta dalam menelusuri informasi dengan cara yang tepat, cepat, dan efisien. Selain ini memberikan pengajaran tentang penelusuruan informasi yang sesuai kebutuhan dan relevan. Kelas LI ini juga menjadi media dalam memperkenalkan digital repository kepada mahasiswa dan dosen. Hal tersebut sangat membantu dalam pengoptimalan pemanfaatan akses digital repository, sehingga para civitas akademika mampu memanfaatkannya dengan maksimal.

\section{b. Peran Digital Repository dalam Tri Dharma Perguruan Tinggi}

Berbagai langkah pengoptimalan pemanfaatan akses digital repository yang dilakukan oleh Perpustakaan Universitas Muhammadiyah Yogyakarta tersebut ditujukan untuk menjunjung Tri dharma Perguruan Tinggi. Adapun peran manfaat digital repository dalam Tri dharma Perguruan Tinggi antara lain:

1) Pendidikan

Semakin berkembangnya informasi dan ilmu pengetahuan yang semakin beragam menuntut civitas akademika khususnya mahasiswa untuk mencari akses referensi yang mudah, tepat, dan efisien demi memenuhi kebutuhan informasi yang sesuai. Perpustakaan Universitas Muhammadiyah Yogyakarta menyediakan berbagai literature atau sumber referensi yang mencakup berbagai bidang, baik yang berkaitan dengan ilmu exacta, sosial, politik, ekonomi, kedokteran, dan lain sebagainya. Sumber bahan referensi tersebut tidak hanya disediakan dalam bentuk fisik semata, namun juga ada beberapa bahan referensi dalam bentul digital. Perpustakaan Universitas Muhammadiyah Yogyakarta menyediakan sumber bahan referensi melalui digital repository yang dapat diakses melalui website www.thesis.umy.ac.id maupun $w w w$. 
repository.umy.ac.id. Kedua website tersebut menyajikan berbagai macam sumber daya informasi digital yang dapat diakses di mana dan kapan saja tanpa terbentur oleh ruang dan waktu. Hal tersebut diharapkan dapat memajukan tingkat kualitas pendidikan mahasiswa kalangan Universitas Muhammadiyah Yogyakata (UMY).

2) Penelitian

Peran perguruan tinggi tidak hanya sekedar menstransfer ilmu pengetahuan kepada mahasiswa, tetapi juga perlu mengembangkan dan mengimplementasikannya melalui kegiatan penelitian yang dilakukan pada semester akhir, seperti melalui skripsi, thesis, maupun disertasi. Penelitian merupakan sebuah kegiatan yang mempengaruhi majunya sebuah perguruan tinggi. Tanpa adanya sebuah kegiatan penelitian, maka perguruan tinggi tersebut akan dianggap sebagai perguruan tinggi yang tidak produktif dan tertinggal dalam hal ilmu pengetahuan. Pada proses pengerjaan penelitian tersebut diperlukan bahan referensi yang mudah didapat, sesuai kebutuhan dan valid. Adanya digital repository di era digital saat ini akan memudahkan mahasiswa dalam menemukan dan mendapatkan sumber referensi dimana dan kapan saja. Dengan tersedianya digital repository tersebut diharapkan dapat menjadi media problem solving dalam proses penelitian dan pengembangan ilmu pengetahuan yang dilakukan oleh para civitas akademika Universitas Muhammadiyah Yogyakarta.

3) Pengabdian kepada Masyarakat

Baik mahasiswa maupun dosen dituntut untuk melakukan kegiatan pengabdian kepada masyarakat dengan mengimplementasikan ilmuilmu yang telah dipelajari di perguruan tinggi, serta diharapkan dapat memberikan contoh yang baik kepada masyarakat luas. Dalam mendukung dan membantu kegiatan pengabdian kepada masyarakat itulah, Perpustakaan Universitas Muhammadiyah Yogyakarta menyediakan akses digital repository yang di dalamnya terdapat berbagai macam referensi informasi dan pengetahuan yang dapat bermanfaat bagi 
mahasiswa maupun dosen dalam mencari referensi relevan dan praktis yang dapat diterapkan di lingkungan masyarakat. Hasil karya civitas akademika dapat diunggah dan diakses melalui digital repository dan dapat diakses oleh siapa saja sesuai dengan hak cipta yang mengikat dengan karya tersebut

\section{Kesimpulan}

Berdasarkan hasil penelitian yang telah dijabarkan, maka didapatkan bahwa Perpustakaan Universitas Muhammadiyah Yogyakarta memiliki strategi dalam usaha optimalisasi pemanfaatan akses digital repository dalam menunjang Tri dharma Perguruan Tinggi, antara lain leaflet dan X-Banner, sosialisasi, media sosial, dan literasi informasi. Strategi optimalisasi tersebut nantinya akan berdampak kepada kemajuan dan keberhasilan perguruan tinggi dalam menyelenggarakan Tri dharma perguruan tinggi dengan baik dan optimal, sehingga akan berdampak positif terhadap reputasi Universitas Muhammadiyah Yogyakarta melalui bentuk pendidikan, penelitian, dan pengabdian kepada masyarakat. Optimalisasi yang paling efektif dapat dilalukan melalui leaflet atau X-Banner dan Literasi Informasi. Dalam penyebaran informasi digital repository melalui leaflet mahasiswa dapat dengan mudah mengambil leaflet yang diletakkan di meja informasi perpustakaan dan dapat disimpan untuk dibawa pulang, sehingga mahasiswa maupun civitas akademika lainnya dapat mengetahui informasi perpustakaan secara ringkas dan praktis. Sedangkan penyebaran informasi digital repository melalui kelas literasi informasi sangat efektif karena dalam kelas tersebut mahasiswa mengetahui bagaimana akses digital repository dengan langsung menggunakan komputer, sehingga mahasiswa dapat mengetahui dengan detail beserta praktiknya. Digital repository Perpustakaan Universitas Muhammadiyah Yogyakarta dapat diakses melalui website thesis.umy.ac.id. Setelah melalui evaluasi, pada tahun 2016 digital repository ditransformasi melalui website repository.umy.ac.id. 
Optimalisasi Pemanfaatan Akses Digital Repository dalam Menunjang Tri Dharma

Perguruan Tinggi

\section{Daftar Pustaka}

Moleong, Lexy J. 2007. Metodologi Penelitian Kualitatif. Bandung: PT. Remaja Rosdakarya.

Pendit, Putu Laxman . 2009. Perpustakaan Digital: Kesinambungan dan Dinamika. Jakarta: Cita Karyakarsa Mandiri. .2007. Perpustakaan Digital:Perspektif Perpustakaan Perguruan Tinggi Indonesia. Jakarta: Sagung Seto. .2008. Perpustakaan Digital dari A sampai Z. Jakarta: Cita Karyakarsa Mandiri.

Sugiyono. 2014. Metode Penelitian Kuantitatif Kualitatif dan R\&D. Bandung: Alfabeta.

Sulistyo-Basuki. 2010. Pengantar Ilmu Perpustakaan. Jakarta: Universitas Terbuka.

Suwardi. 2014. "Peran Pustakawan Dalam Pengembangan Institutional Repository: Sebuah Tantangan” dalam Majalah Visi Pustaka Vol. 16 No. 1 diakses melalui http://www.pnri.go.id/magazine-kind/visipustaka/ pada tanggal 08 Oktober 2017.

Suwarno, Wiji. 2016. Ilmu Perpustakaan \& Kode Etik Pustakawan. Yogyakarta: Ar-Ruzz Media. 